\title{
Value Chain Governance of Malawi's Artisanal Fisheries: A Case of Oreochromis Species
}

\author{
Letson Y. Phiri ${ }^{1}$, Joseph Dzanja ${ }^{2}$ \& Tasokwa Kakota ${ }^{3}$ \\ ${ }^{1}$ Aquaculture and Fisheries Science Department, Lilongwe University of Agriculture and Natural Resources, \\ Lilongwe, Malawi \\ ${ }^{2}$ Agri-Business Management Department, Lilongwe University of Agriculture and Natural Resources, Lilongwe, \\ Malawi \\ ${ }^{3}$ Basic Sciences Department, Lilongwe University of Agriculture and Natural Resources, Lilongwe, Malawi \\ Correspondence: Letson Y. Phiri, Karonga Fisheries Office, P.O. Box 111, Karonga, Malawi. Tel: \\ 265-999-687-649. Email: yoyola_phiri@yahoo.co.uk
}

Received: April 30, 2015 Accepted: May 14, 2015 Online Published: August 15, 2015

doi:10.5539/jas.v7n9p93 URL: http://dx.doi.org/10.5539/jas.v7n9p93

\begin{abstract}
Value chain governance refers to the relationships among the buyers, sellers, service providers and regulatory institutions that operate within or influence the range of activities required to bring a product or service from inception to its end use. This paper analyses value chain governance in the Oreochromis species (Chambo) value chain. The establishment of value chain governance is likely to lead to improvement in the management of Chambo value chain. The paper examines the different marketing strategies, the opportunities, challenges, the upgrading strategies and the nodes that are along the Chambo value chain. Using empirical evidence, chi-square had a value of 0.154 with an asymptotic significance of 0.926 , indicating lack of evidence that value chain stages of Chambo in different strata were not the same. Underrating any stage along the chain has negative economical implications considering that any stage along the chain is supportive to majority of the people. The actors along the chain must learn to be innovative so that they are able to find suitable methods for marketing their fish.

It has also been found that crew members benefit less than the gear owners in the chain rewards distribution. Dealing with marketing and distribution constraints, improvement in the working conditions of fishers may lead fishers to maximize their capability by sustainably exploiting the resource and that may have positive impact to both consumers and retailers. Upgrading is helpful as it reduces chain risks at all levels or stages of the value chain.
\end{abstract}

Keywords: constraints, distribution, marketing, net share, opportunities, rewards, upgrading and value chain governance

\section{Introduction}

\subsection{Background}

Lake Malawi is endowed with numerous fish species that are endemic to the lake. Some of the species commonly found in Lake Malawi are Oreochromis species popularly known as Chambo. Oreochromis lidole, Oreochromis squampinnis and Oreochromis karongae are the three Oreochromis species that form the basis of important commercial species for both commercial fishers and artisanal fishers (Seisay, Van Zalinge, \& Turner, 1992). Oreochromis spp. contributed $2.4 \%$ to the total fish production and the same percentage in terms of total fish value (GoM, 2011). The introduction of Chambo Restoration Strategic Plan (CRSP) is evident that the fish have significant importance in Malawi and it outlines measures to conserve the Chambo in the wild apart from being a comprehensive aquaculture research plan for the fish (Banda, Jamu, Njaya, Makuwira, \& Maluwa, 2005).

\subsection{Value Chain Governance}

Value chain governance as a way value chains are organized, coordinated and also the existence of power relations amongst different value chain actors (Herr, 2007). It's also defined as organizing of activities with the purpose of achieving a certain functional division of labour along a value chain which result in specific 
allocations of resources and distribution of gains (Bolwig et al., 2008). Value chain governance is categorized according to power asymmetry which increases as we move from left to right. There are five types of global value chain governance that are used and these are market relationships, modular relationships, relational relationships, captive relationships and hierarchical relationships (Herr, 2007; Gereffi, Humphrey, \& Sturgeon, 2005). In modular relationships, the supplier provides services to customers' specifications and suppliers become highly competent. Relational relationships have complex interactions between buyers and sellers and there is mutual dependence and asset specificity. Captive relationship is a situation whereby small suppliers are transactional dependent on a much larger buyer. Suppliers in captive relationships do not easily switch to other buyers because of heavy costs attached to such a move and may remain captive. Hierarchical relationship is where a very powerful firm takes over control or ownership of other parts of the value chain while market relationship is where there are interactions between buyers and sellers on equal basis but there is very little exchange of information and learning from each other. The exchange conditions in market relationship are negotiated daily basing on market price. Governance is important from a policy perspective as it assists in identifying the institutional arrangements that may need to be targeted to improve capabilities in the value chain, remedy distributional distortions and increase value added in the sector (M4P, 2008).

Upgrading is defined as a desirable change in chain's participation that enhances rewards and reduces exposure to risks and means of acquiring capabilities and accessing new market segments through participating in particular chains (Riisgard et al., 2008; Humphrey \& Schmitz, 2006a). It has been noted that an analysis of upgrading involves actors' profitability assessment and also information constraints currently present in the chain to identify the possibilities for producers to move up the value chain either by shifting to more rewarding functional positions or by making products that have more value-added invested in them or that can provide better returns to producers (M4P, 2008; Bolwig et al., 2008). Humphrey and Schmitz (2002b) came up with four types of upgrading strategies and these are process upgrading whereby there is more efficient transformation of inputs into outputs achieved after reorganizing productive activities, product upgrading which involves movement into more sophisticated products with increased value, functional upgrading which refers to acquiring of new functions to increase skills and lastly there is inter-chain upgrading whereby one's skills acquired from a chain are used in a different chain.

Value chain can be used to display information on numbers of participants, employment by each participating group, gender disaggregation of employment and value added at each function (Kula, Downing, \& Field, 2006). Value chain map is a graphic depiction of the structure and functions in a particular value chain and is useful in illustrating relationships between firms. Value chain mapping using chain-wide learning is aimed at identifying the institutions and policies that are critical to the inclusion or exclusion of small-scale producers (Vermuelen, Woodhill, Proctor, \& Delnoye, 2008). Broad based growth reduces poverty, diminishes the burden on public resources to mitigate poverty's adverse effects. This increases the purchasing power of the poor consumers as they increase their consumption on goods and services that are more locally produced than those of wealthy consumers, this creates demand for goods and services and in turn creates demand for increased labour force thereby achieving increased employment, wages and consumption (Prahalad \& Hart, 1999). This therefore means that government policies that aim at improving the growth of the economy though important but consideration should also be put on mechanisms for narrowing income gap between the rich and the poor in order to achieve meaningful economic growth. In countries where there are large income gaps between the rich and the poor, the rich benefit from economic growth far earlier and for longer than the poor. Where income gaps are relatively small, growth translates into poverty reduction much more quickly and efficiently (Ravaillon, 2004).

The state apparatus in Malawi did not encourage the development of the fisheries sector as middlemen referring to traders were left to evolve on their own (Hara \& Mkoko, 1992). Little has been done to understand the value dynamics of the fisheries sector, there is lack of adequate understanding of the exact value of fisheries with reference to livelihood strategies of the fishing communities (Chisinga, 2008). Hence, there is correspondingly limited systematic understanding of the ways of life in areas where fishing is a sole means of livelihood. In summary very little has been done concerning value chain governance of the fisheries sector in Malawi.

Chambo being one of the important fish species in Malawi, undertaking this study was necessary as it provided an insight of how Chambo value chain is operated. This also provided an opportunity for suggesting ways of how the chain could further be improved and strengthened in case of existing weak areas along the chain.

The overall objective of the study was to analyze the value chain governance of Chambo. Specifically the study (1) identified the value chain stages or nodes for Chambo (2) investigated the relationships among different actors along the value chain (3) determined how different relationships influence the efficiency of the chain (4) 
analyzed the different marketing strategies existing along the chain (5) examined the opportunities and challenges and the upgrading strategies different actors would want to use along the Chambo value chain. The hypothesis was that Chambo value chain stages are not the same in different locations or strata.

\section{Materials and Methods}

\subsection{Study Area, Sampling and Data Collection Methods}

The research was done in 2012 in Mangochi District which was purposively selected because it is where most of the Chambo fish caught in Malawi comes from. Lake Malawi has almost close to 30 strata which are numerical points from where fisheries data are collected. Mangochi alone has seven strata and six of them are in the south east arm of lake Malawi and these are strata 2.1, 2.2, 2.3, 2.4, 2.5 and 2.6 while the seventh one is in the south west arm of the lake and is called stratum 3.1. Strata 2.1, 2.2 and 2.3 were purposively selected for data collection and this was due to resource limitation and proximity because the other areas were hard to reach. Stratified sampling technique was applied followed by simple random sampling technique to identify respondents and a total sample size of 124 people (30 fishers, 31 wholesalers, 33 retailers and 30 consumers) were sampled. Cross-sectional data was collected through individual interviews using semi structured questionnaires. Professional opinion was collected from government staff, influential and experienced members of the fishing communities through key informant interviews. Data from fishers were collected from strata 2.1, 2.2 and 2.3 and data for fish wholesalers and retailers were collected from the same strata where fishers' data were collected and also from Mangochi and Limbe markets. Chain wide learning method developed by Vermeulen et al. (2008) was also used to collect qualitative data from 30 people comprised of fishers, fish traders and Beach Village Committee (BVC) members. BVCs are local committees that are responsible for managing the fish resources and represent the interests of the fishing communities but also play as a link between those communities and the Department of Fisheries. Three sessions were held comprising 10 people per session who were doing different fishing activities but had come from different beaches within each stratum.

\subsection{Data Analysis}

Qualitative data analysis methods were applied to the collected data from key informant interviews and chain wide learning method. The data were organized into required themes and topics obtained from literature search. The data were categorized and then searched for the text that matched the listed themes or topics. Second method for analyzing qualitative data was done by going through the data to identify areas that were relevant and of interest (content analysis). Quantitative data was analyzed using computer software such as statistical package for social scientist (SPSS) to come up with both inferential and descriptive statistics. Excel spreadsheets were also used to compute profits for the chain.

\section{Results and Discussion}

\subsection{Value Chain Mapping}

The research established the nodes through which Chambo passes, mapped the chain actors involved at different nodes of the chain, mapping of participants at the production node, the marketing strategies used at the production node, the chain rewards, geographical spread of the chain and the constraints and opportunities along the chain.

The three different locations in which the chain-wide learning was done came up with the same chain nodes relatively though some had indicated more stages and activities than others. A chain done by a group at Malindi (stratum 2.2) had four nodes and these were fishing (production), wholesaling, retailing and consumption. The Malindi group indicated auctioning and distribution as the functions that take place. A group at Kela (stratum 2.1) had indicated four nodes (fishing, wholesaling, retailing and consumption) and the functions that were indicated as taking place before fishing were procurement and recruitment while those functions within the chain nodes were fish preservation, transportation, and facilitation of buying process by middlemen or agents. The Madzedze group (stratum 2.3) had indicated five stages namely: fishing, fish processing, wholesaling, retailing and consumption. The functions indicated as taking place within the chain of Chambo by the Madzedze group were fish auctioning and fish distribution. Although fish processing was mentioned as one of the stages, no evidence was found that Chambo was being processed in any form by the small-scale fishers. The fish may be processed through smoking only if there is oversupply of the fish but because the fish is on high demand mostly was being sold fresh. 


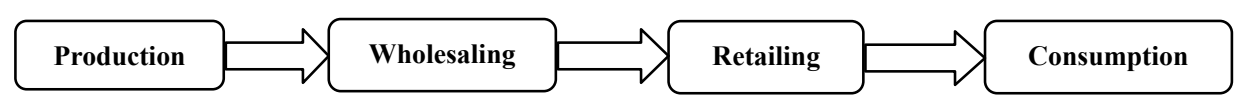

Figure 1. A typical Chambo value chain framework showing chain nodes

Source: This research, 2012.

Empirical results using Chi-Square test had a value of 0.154 with an asymptotic significance of 0.926 indicating lack of evidence that value chain stages of Chambo in different strata were not the same (Table 1).

Table 1. Chi-square statistics

\begin{tabular}{llll}
\hline Area in particular stratum & Observed number of chain stages & Expected number of chain stages & Residual \\
\hline Malindi (stratum 2.2) & 4 & 4.3 & -0.3 \\
Madzedze (stratum 2.3) & 5 & 4.3 & 0.7 \\
Kela under Namiasi (stratum 2.1) & 4 & 4.3 & -0.3 \\
Total & 13 & & \\
\hline Test statistics & Chain stages in the strata & & \\
\hline Chi-squarea & 0.154 & & \\
Df & 2 & & \\
Asymptotic significance & 0.926 & & \\
\hline
\end{tabular}

Note. 3 cells (100.0\%) have expected frequencies less than 5 . The minimum expected cell frequency is 4.3 .

The chain has fewer stages than the number of actors taking part in the chain's activities. The chain actors are either directly involved in transacting fish business or are indirectly involved through facilitation of fish business transaction. Fish transporters are the actors that are not directly involved but offer their services for the success of Chambo value chain. Figure 2 are actors that are directly involved in Chambo value chain transactions:

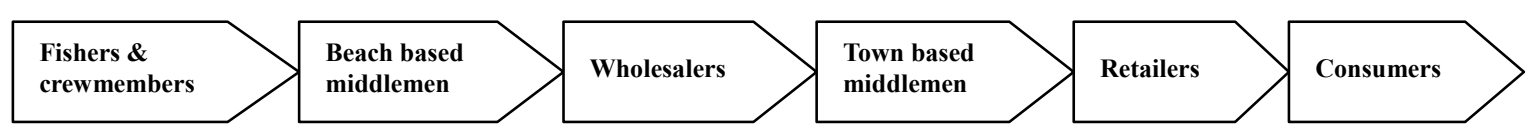

Figure 2. Value chain actors operating along the Chambo value chain

Source: This research, 2012.

\subsection{Mapped Participants}

In the course of mapping actors at the production node for 30 fishing fleets that were targeted for individual interviews, it was found that different fishing gears had different number of fishing gear operators. The operation of Chilimira fishing gear was mostly done by hired personnel referred to as crew members while most of the gear owners were not actively involved in fishing. Chilimira is an open water seine net used at night times with the help of light mainly to catch Usipa (Engraulicypris sardella) but also catch Chambo and is referred to as kauni fishing. The gear is also used during day time but the Chilimira operators that were interviewed were those operating at night. The thirteen Chilimira fishing fleets had 115 active crew members and 3 active gear owners making a total of 118 active fishing operators and 10 inactive gear owners (Table 2). 
Table 2. Number of individuals involved in the operation of Chilimira

\begin{tabular}{llll}
\hline ID No. & No. of fishers & No. of crew members & Total involved \\
\hline 30 & 1 & 8 & 9 \\
28 & 0 & 10 & 10 \\
25 & 0 & 9 & 9 \\
24 & 0 & 9 & 9 \\
22 & 0 & 9 & 9 \\
21 & 0 & 9 & 9 \\
20 & 0 & 9 & 9 \\
19 & 1 & 8 & 9 \\
18 & 0 & 9 & 9 \\
17 & 0 & 9 & 9 \\
16 & 0 & 9 & 9 \\
14 & 0 & 9 & 9 \\
13 & 1 & 8 & 9 \\
Total & 3 & 115 & 118 \\
\hline
\end{tabular}

Note. $0=$ inactive fisher, $1=$ active fisher.

A Nkacha which is non-selective and prohibited fishing gear in Lake Malawi had 1 gear owner and 7 crew members totalling to 8 while drag net was operated by 1 fisher and 3 crew members and came to a total of 4 (Table 3). The six gillnets were operated by 5 gillnet operators and 16 crew members making it 21 while 1 gear operator was inactive (Table 4). There were 9 fishers operating hand or long lines (Table 5). In general, a total of 160 individuals inclusive of 118 chilimira operators were actively involved in fishing activities. The 10 inactive chilimira gear owners and 1 inactive gillnet owner plus 160 active individuals led to a total of 171 individuals directly benefiting from 30 fishing fleets. The 171 people exclude their family members whose livelihoods are also dependent on fisheries. If it is conceptualized that the 171 individuals are household heads and basing on the average household size for Malawi of 4.6 individuals according to National Statistical Office (NSO) and ICF Macro (2011) this might translate to 787 individuals being dependent on 30 fishing fleets for their livelihoods.

Table 3. Number of individuals involved in the operation of Nkacha and dragnet

\begin{tabular}{llll}
\hline ID No. & No. of fishers & No. of crew members & Total involved \\
\hline 12 (nkacha) & 1 & 7 & 8 \\
5 (dragnet) & 1 & 3 & 4 \\
\hline
\end{tabular}

Table 4. Number of individuals operating gillnets

\begin{tabular}{llll}
\hline ID No. & No. of fishers & No. of crew members & Total involved \\
\hline 23 & 1 & 3 & 4 \\
15 & 1 & 3 & 4 \\
10 & 1 & 3 & 4 \\
7 & 0 & 4 & 4 \\
6 & 1 & 3 & 4 \\
1 & 1 & & 1 \\
Total & 5 & 16 & 21 \\
\hline
\end{tabular}

Note. $0=$ one inactive fisher, $1=$ one active fisher. 
Table 5. Individuals operating hand and long lines

\begin{tabular}{lll}
\hline ID No. & No. of fishers & Total involved \\
\hline 29 & 1 & 1 \\
27 & 1 & 1 \\
26 & 1 & 1 \\
11 & 1 & 1 \\
9 & 1 & 1 \\
8 & 1 & 1 \\
4 & 1 & 1 \\
3 & 1 & 1 \\
2 & 1 & 1 \\
Total & 9 & 9 \\
\hline
\end{tabular}

\subsection{Marketing Strategies}

The marketing strategies the Chambo value chain actors use at the beach are in two folds and these are direct selling and auctioning.

\subsubsection{Direct Selling}

In direct selling, either a wholesaler or middleman directly negotiates for fish prices with the fisher or fishing crew members. Direct selling mostly takes place when there are few buyers to the extent that they don't need to struggle to buy the fish and the fish quantities being sold are not enormous. Apart from having low fish demand, this kind of fish selling is also area specific. At Mwawa beach (stratum 2.1) and Madzedze area (stratum 2.3), direct fish selling is practiced.

\subsubsection{Fish Auctioning}

The fish marketing strategy whereby fish selling is done through auctioning was observed at night times and at specific landing beaches such as Namiasi (stratum 2.1). This is done whereby either middlemen or wholesalers outbid each other by indicating fish prices they are ready to offer for the fish. Fish selling through auctioning is done by Chilimira or kauni fishers. They use three fishing crafts which are either two boats with one canoe for each fishing fleet or two canoes with one fishing boat. Once they land their catches and as they are approaching the landing beach they leave some of their fish catches in boat(s) away from the beach and come to the landing beach with just part of their fish catches. They do not want the buyers to know the exact fish quantities that have been caught as that may affect fish pricing. The intention of doing this is to control the fish supply so that buyers should compete for low fish supply in order for them to have their fish catches sold at good prices. This kind of fish selling involves huge quantities of fish.

\subsection{Selling Fish through Middlemen}

In both direct fish selling and auctioning, beach based middlemen may be present or not depending on the circumstances. If a wholesaler is familiar to the fishers, sometimes he may not need to go through the middlemen because a fisher and a wholesaler may sometimes have a business linkage whereby a wholesaler may be providing support for fishing operations to the fisher. In such a situation, a fisher is committed to selling the fish to such a wholesaler. This was also reaffirmed by a wholesaler while having individual interviews. In certain cases especially when wholesalers are strangers to the fishing area, it becomes difficult for them to manage to buy fish unless they buy through beach based middlemen. The relationships between fishers and beach based middlemen are in most cases deep rooted since they are sometimes related either by blood or by having their fishing villages close to each other. The middlemen once they do the work on the wholesalers' behalf, they are paid a fee that is agreed between the two. There was great variation in the amount of fee that was paid to middlemen for transacting business with fishers on behalf of wholesalers and ranged from (Note 1) US\$1.16 to US $\$ 1.74$ per dozen of fish, for a tin of fish US\$2.91 was paid to middlemen and sometimes middlemen could be paid US $\$ 5.81$ for a day's service. Beach based middlemen's benefits depended on fish quantities whether in dozens or tins wholesalers were willing to buy from fishers.

Town based middlemen are responsible for handling fish selling transactions with retailers on behalf of fish wholesalers once wholesalers take their fish to urban markets. The fish wholesalers in urban markets are not allowed or given space to sell the fish to retailers themselves and the situation forces them to sell their fish 
through middlemen. The urban based middlemen have customers (retailers) who come from different smaller urban markets to purchase fish from them. The fee in town paid to middlemen for transacting fish business on behalf of a wholesaler ranged from US\$8.72 to US\$11.63.

\subsection{Rewards, Net Share, Relationships and Chain's Geographical Spread}

\subsubsection{Distribution of Benefits at Production Node}

The sharing of benefits by fishing operators is also dependent on the fishing type being practiced. Fishers whose fishing activities do not require involvement of hired labour, the benefits realized are not shared with anybody. In the case of Chilimira, gillnet and Nkacha fishing gear operators, the benefits realized are shared equally between gear owner and crew members but this is after all the expenses incurred as variable costs have been deducted. The $50 \%$ of the profits made per fishing trip is taken by the gear owner and the other $50 \%$ is shared among crew members. Basing on the mapped number of participants ( 30 fishers and 141 crew members) operating at production node, the day's profits totalled US\$742.78 and were shared in such a way that fishers had US\$467.95 which was $63 \%$ of the chain's profits and crew members had US $\$ 274.83$ which was $37 \%$ of the total chain's profits (Table 6). The profits were also redistributed according to the gear type and US\$193.12 (26\%) were the profits realized from those that were using hand lines, profits from those using chilimira were US\$215.41 (29\%) and profits from gillnet operators were US\$334.25 (45\%). The money allocated to fishers was more than what crew members got and the increase was because the money fishers got through fishing using hand lines was not shared with anyone since crew members are usually not employed in this type of fishing. The computation shows that fishers benefit more than crew members since the money crew members share is very meagre as compared to those of fishers. The current arrangement for resource or rewards distribution may not render the crew members to enjoy the fish proceeds equally the same as fishers because crew members are not the owners of fishing gears and crafts. The sharing of proceeds by crew members too is dependent on the role the crew member played when fishing, for instance in certain type of fishing where diving is involved, those that dive in water in case the net has entangled somewhere or they dive to hunt for fish are given an extra share to make it more than their colleagues.

Chambo business was also found to be male dominated basing on the number of interviewees that were randomly selected for semi-structured questionnaire interviews. Out of the 30 fishers interviewed, none was a woman. Amongst the 31 Chambo wholesalers only one was a woman (3.2\%) and the rest were men (96.8\%). The interviewed Chambo fish retailers also did not include a woman. This confirms what Kambewa, Nagoli and Husken (2009) reported that fresh Chambo business is mainly handled by men the reason being because of capital and labour intensiveness.

Table 6. Daily wage income distribution for fishers

\begin{tabular}{lllll}
\hline Item & US\$/dozen & dozen/actor & No. of actors & Total (US\$) \\
\hline Fishers' operating costs & 1.26 & & & 733.07 \\
Fishers' wage costs & 3.39 & 7.203 & 30 & \\
Fishers' other costs (fixed) & 0.44 & & & \\
Fishers' total costs & 5.09 & & & 742.78 \\
Fishers' revenue & 8.53 & & 30 & \\
Fishers' profit & 3.44 & 7.203 & & \\
\hline
\end{tabular}

Source: This research, 2012.

\subsubsection{The Net Share of the Consumer Price}

The fishers had $26.78 \%$ of the consumer's price, wholesalers had $54.68 \%$ of the consumer's price and fish retailers had $67.84 \%$ of the consumer's price (Table 7). This meant that the fish retailers were able to rip more benefits than the rest of the chain actors (fishers and wholesalers) while fish wholesalers were second to rip more of the chain's benefits and fishers were the least to rip the benefits. This was the case because fishers could incur a lot of costs through wages paid to crew members and also through procurement of fuel which was mostly bought from vendors when fuel pumps were dry during the 2012 fuel crisis of Malawi. The fish wholesalers incurred more costs through transportation than any other expense while with fish retailers, the expenses were 
not that significant as they bought fish brought to them by wholesalers. Although fish retailers could take the fish to other markets but such processes were taking place within short distance areas. Fish retailers had control over the chain basing on the benefits that they were able to enjoy and apart from this they could not allow fish wholesalers to have stalls from where wholesalers could directly sell their fish to consumers. Fisher's marketing margin was the same as fisher's marketing profit and this was due to the fact that fishers were selling fish at the beach and could not incur marketing costs as was the case with fish retailers and wholesalers. The marketing costs that both fish wholesalers and retailers incurred were on transport, ice while packaging costs were incurred by retailers only. The marketing costs are inclusive in the marketing margin as this is the difference between sales price and purchase price. Marketing profit is the profit obtained after subtracting purchase price and marketing costs from sales price.

Table 7. Net share of different value chain actors of the consumer's price in local currency (Malawi Kwacha)

\begin{tabular}{lll}
\hline Actors and marketing particulars & MK/dozen & Share of consumer's price \\
\hline Fishers & 875.78 & 26.78 \\
Purchase price/dozen & 1467.01 & \\
Sales price/dozen & 0 & \\
Marketing costs/dozen & 591.23 & \\
Marketing margin & 591.23 & \\
Marketing profit & & 54.69 \\
\hline Fish wholesalers & 1788.37 & \\
Purchase price/dozen & 2478.02 & \\
Sales price/dozen & 273.81 & \\
Marketing costs/dozen & 689.65 & \\
Marketing margin & 415.84 & \\
Marketing profit & & \\
\hline Fish retailers & 2218.57 & \\
Purchase price/dozen & 3270.27 & \\
Sales price/dozen & 214.48 & \\
Marketing costs/dozen & 1051.70 & \\
Marketing margin & 837.22 & \\
Marketing profit & 3270.27 & \\
\hline Fish consumers & & \\
Purchase price/dozen & & \\
\hline
\end{tabular}

Source: This research, 2012.

\subsubsection{Relationships among Chain' Players}

Along the Chambo value chain there are relationships which facilitate the proper transfer of fish products from production stage to the end markets. The governance types for Malawi's small scale fishery can be in two or three folds depending on circumstances and these may be market type, relational type and captive type of governance.

Fish wholesalers transact their business by supplying their fish to any retailer they are free to supply to, the costs are not complex and market linkages develop and this is what is referred to as market type of chain governance. Other examples of market type of chain governance along the Chambo value chain is what happens at Makawa beach whereby beach based middlemen manage to pull their resources together in form of savings. They use such savings to buy fish in case there are no fish wholesalers at the beach to buy fish from the fishers. After buying the fish they network with fish wholesalers to buy fish from them and if this is not possible they operate as fish retailers. These beach based middlemen save the fishers from experiencing fish loss through quality deterioration. The other relationship is where town or urban-based middlemen are able to network with both fish wholesalers and fish retailers by transacting business with fish retailers on behalf of fish wholesalers. The fish wholesalers are able to have the fish market because of the town based middlemen since they are the ones 
controlling the market as they are able to know most of the markets where fish retailers operate from and in case of failure by retailers to pay back the money for the purchased fish, the town based middlemen are able to trace the whereabouts of such fish retailers something that fish wholesalers may not manage to do.

Sometimes fishers sell their fish catches to wholesalers with whom they have built long time relationship or else a situation whereby the two may be related by blood and such type of governance is relational type. Apart from blood relationships are the informal arrangements that are made based on trust amongst the wholesalers. They sometimes bulk their fish products and send few individuals selected amongst themselves to far away markets to transact business on behalf of other wholesalers. That is a mechanism of reducing transport costs in a relational relationship.

The confirmation by one of the fishers that sometimes are given resources by fish wholesalers to facilitate fishing activities can sometimes put fishers in a kind of captive type of governance. This may be the case since fishers may be required to sell their fish to none other than those supplying resources for fishing activities. Such arrangements may also have some hiccups since the buying of fish by wholesalers may not be as competitive as is the case with auctioning. This type of governance occurs in rare circumstances but the commonly used is the market type.

\subsubsection{Geographical Spread of Chambo Value Chain}

The markets for Chambo from Mangochi District span from Mangochi itself to other districts in the southern and central regions of Malawi. Some of the districts where Chambo of Mangochi is taken to are Zomba and Blantyre particularly in Limbe in the southern region and Lilongwe in the central region. The distance from Mangochi to Zomba and Limbe is not less than $127 \mathrm{~km}$ and $191 \mathrm{~km}$ respectively. In central region, Chambo from Mangochi is taken to Lilongwe Central Market and the chain spans over $245 \mathrm{~km}$. At Lilongwe Central Market, Chambo is further distributed to other smaller markets within the district.

\subsection{Constraints, Opportunities and the Upgrading Mechanisms}

Value chain actors are faced with constraints which affect the proper functioning of the value chain. The constraints affect all the nodes starting with production, wholesaling and retailing. The challenges require mechanisms of addressing them for the betterment of the value chain while also putting to good use the opportunities that are there.

\subsubsection{The Constraints}

\section{1) Wholesalers}

In some markets, wholesalers are faced with organized theft once they insist to sell the fish on their own without involving the middlemen as the buyers come with colleagues and take advantage that the wholesaler is new and steal some of his/her fish. Exclusion has also been a common phenomenon as they are denied space for which they can use to sell their fish and such exclusion also happens at the beaches as they are told to buy fish from fishers through middlemen. The markets have inadequate cold chain facilities for maintaining fish quality if not none at all and this entails that if fresh Chambo is taken to such markets, it has to be sold out within the shortest possible period before fish quality starts to deteriorate to avoid loss of value. The wholesalers incur high costs on food and accommodation whenever they take their fish to far away markets and that affect their business profits. Fuel scarcity have had an effect on the distribution and quality of Chambo in terms of freshness since the situation normally leads to the delay in taking the fish to the market and in the process fish quality is compromised.

\section{2) Fishers}

Fishers have been involved in disasters like capsizing of fishing boats and canoes once they go out fishing. This happens due to heavy winds blowing on the lake or high water waves resulting in their failure to reach the beach on time. The situation is exacerbated by their use of boats and canoes without engines and apart from this life jackets are hardly used. They also lose their fishing nets such as gillnets as they are left over night once they are set in water and in the process sometimes they lose their fish catches through theft and also lose nets once they are entangled to trawling nets or other gears used to fish at night times. They are also prone to attacks by hippos and crocodiles and sometimes lose their lives in the process of fishing or setting their fishing nets.

\section{3) Fish Retailers and Consumers}

Sometimes the oversupply of Chambo affects its pricing which tend to be very low and such a situation affects fish retailers' profits although it is a positive and welcome development for consumers as the fish becomes affordable to them. The impact of low Chambo catches is borne by the consumers since this leads to 
skyrocketing of fish prices.

\subsubsection{Opportunities}

The involvement of different actors along the value chain provides the actors with the opportunity of learning and knowing new things. Certain markets have labourers that are of good character and able to respect other people especially when they are hired to do some work for a pay and they do not demand unjustifiable payment from whosoever has hired them but this is not the situation in all the markets. There are also certain markets where wholesalers are not denied space for doing business though such markets are not very common. Presence of tourists in cottages makes small-scale (artisanal) fishers to sell their fish at reasonable prices. Generally Chambo still enjoys the market potential even in far away markets. Open access to fishing provides an opportunity for everybody willing to engage in fishing to do so as long as one has the fishing equipment that is licensed.

\subsubsection{Upgrading}

Upgrading reduces the chain risks by providing solutions to constraints which would have otherwise led to failure of the value chain. It becomes handy through identification of leverage points which are used for the improvement of the chain. The Chambo value chain also needs improvement and the suggested possibilities aim at tackling the constraints of the production node that fishers face (Appendix 1). Fishers lose gillnets through trawling operations and by intensifying patrols to enforce trawling times, artisanal fishers fishing nets could be spared from damage and that could be helpful to them as their fishing frequency could increase hence leading to increase in earnings because of decrease in number of days for maintenance or repairing of their damaged fishing nets. Instituting a policy so that use of life jackets in Lake Malawi should be mandatory could help to reduce deaths that are caused due to boat accidents because of strong water waves or mechanical faults. Although fishers are unable to afford having boats with engines which can take them offshore, the Malawi Government in an attempt to stimulate fish production from deeper waters of Lake Malawi considered to be underexploited introduced tax free facility for importation of fishing equipment and gears (GoM, 2002). If such an opportunity could be utilized apart from increasing fish production there may be a reduction in deaths that they are prone to when setting their nets in-shore because of hostile crocodiles and hippos. The exclusion that wholesalers experience both at the beaches and in the markets may be dealt with if wholesalers come together to form an association so that they may deal with their constraints as a group. Their grouping may as well assist them in engaging government on matters that may not be dealt with by an individual for instance the issue of infrastructure development in the markets and at the beaches may only be solved if they have a very strong group to lobby for improvement from government. The high costs wholesalers say they incur through food, accommodation and transport may be dealt with if they learn to bulk their fish when going to markets, that may assist them to reduce expenses as there is cost sharing since few individuals may be required to sell products on behalf of a number of people. The fuel issue which was leading to their delay to the market to sell the fresh fish could have been tackled at community level. This could require the acquirement of skills for smoking fish so as to extend the fish's shelf life and at the same time this smoking could assist them to reduce the fish volume for fresh fish thereby allowing them to carry more of smoked fish to markets. Sharing of marketing information could be very vital for retailers and other actors along the chain as this would assist them to know in advance where there is fish oversupply in order to come up with alternatives and in so doing unnecessary costs could be avoided. Low catches heavily impact on the consumers regardless that this affects other actors in the chain too.

\section{Conclusion and Recommendation}

It has been observed that the livelihoods of so many people are dependent on fisheries resources as such sustainable exploitation of the resource must always be a priority. The lake provides a source for employment and this reduces pressure which government should have had, had it been that all those working in the fisheries sector had nothing to do. The presence of market based middlemen along the chain though contributes to the increase in the margins in most cases but is helpful as they are the ones who have the (customers) for Chambo because of their long stay in the markets unlike wholesalers. Fishers' marketing strategy which involves auctioning may be prone to colluding on prices amongst the fish buyers and middlemen. The sharing system of fishing proceeds favours the gear owners referred to as fishers as they have the opportunity to get away with a good chunk of money realized from fishing because of the existing arrangement. Crew members for each fishing fleet outnumber the fisher and the existing sharing system does not favour the crew members. It would be necessary if a deliberate policy could be put in place so that crew members are put on fishers' payroll as such they would be protected from exploitation, the fisher would be asked to insure his/her fishing workforce considering the risks that are associated with fishing and at the same time it may be possible to exploit the 
resources sustainably as crew members may not be driven by need for immediate benefits which urge them to use fishing methods that are not legal.

The geographical spread for Chambo is very wide and that is an indication that the fish is very important and if Malawi is to venture into fish exports this may be the fish to target but after finding means for mass production of the fish. An export market may not be the only market; domestic market can also provide potential but after intensive promotion of consumption. The fish can also become affordable to most Malawians if produced massively in culturing facilities like ponds or cages because of economies of scale. Such a move may likely improve the country's economy and create employment for the masses since other industries to support such an initiative may be borne in the process for instance feed and seed industries. Such initiatives may also be helpful to those operating in the transport sector as there may be need to go into contract farming which may likely demand legal arrangements. Introducing large scale schemes for aquaculture production may be the only option to achieve this which may also require putting in place good road networks and electricity. The roads may facilitate quick delivery of inputs to farmers and delivery of fish harvests to fish processing plants. All these may function successfully if there is provision of electricity.

\section{Acknowledgements}

We wish to acknowledge the role played by the Lilongwe University of Agriculture and Natural Resources (LUANAR) formerly known as Bunda College of Agriculture whilst under the University of Malawi for coordinating this research. We also thank Regional Universities Forum (RUFORUM) for providing financial support for carrying out this research and not forgetting PLAAS for co-sponsoring the research, workshops and trainings for pro-poor value chain governance in Southern Africa.

\section{References}

Banda, M., Jamu, D. M., Njaya, F., Makuwila, M., \& Maluwa, A. (2005). The Chambo Restoration Strategic Plan: Proceedings of the 2003 National Workshop (p. 112). Mangochi, Malawi: WorldFish Centre Contribution 1740.

Bolwig, S., Ponte, S., du Toit, A., Riisgaard, L., \& Halberg, N. (2008). Integrating Poverty, Gender and Environmental Concerns into Value Chain Analysis: A Conceptual Framework and Lessons for Action Research. DIIS Working Paper No. 2008/16. Danish Institute for International Studies, Copenhagen, Denmark.

Chisinga, B. (2008). Policy and Institutional Framework of the Fisheries Sector in Malawi. Chancellor College, University of Malawi, Zomba, Malawi. Retrieved from http://www.ndr.mw:8080/xmhui/bitsstream/handle

Gereffi, G., Humprey, J., \& Sturgeon, T. (2005). The Governance of Global Value Chains. Review of International Political Economy, 12(1), 78-104. http://dx.doi.org/10.1080/09692290500049805

GoM. (2002). Trade Policy Review. Malawi. Retrieved from https://docs.wto.org/dol2fe/Pages/FE_Search/FE_S S006.aspx?Query

GoM. (2011). Annual Economic Report. Ministry of Development Planning and Cooperation, Lilongwe, Malawi.

Hara, M., \& Mkoko, B. (1992). Case of Improving Marketing of Fish in Malawi. In F. Teutscher (Ed.), Post-Harvest Technology: Proceedings of the 1990 Symposium (CIFA Technical Paper No. 19). Cairo, Egypt. Retrieved from http://www.fao.org/docrep/005/t0606B05.htm\#ch5

Herr, M. L. (2007). An Operational Guide to Local Value Chain Development: Combining Local Economic Development (LED) with Value Chain Development (VCD) to strengthen Competitiveness and Integration of SMEs into Markets. International Labour Organization, Colombo, Sri Lanka.

Humphrey, J., \& Schmitz, H. (2008a). How does Insertion in Global Value Chains Affect Upgrading in Industrial Clusters? Regional Studies, 36(9), 1017-1028. http://dx.doi.org/10.1080/0034340022000022198

Humphrey, J., \& Schmitz, H. (2008b). Developing Country Firms in the World Economy: Governance and Upgrading in Global Value Chains. INEF Report 61/2002. Duisburg: INEF-University of Duisburg.

Kambewa, P., Nagoli, J., \& Husken, S. M. C. (2009). Vulnerability of Female Fish Traders to HIV/AIDS along the Fish Market Chain of the South East Arm of Lake Malawi. Analysis Report, Regional Programme Fisheries and HIV/AIDS in Africa: Investing in Sustainable Solutions. Worldfish Center, Project Report 1979.

Kula, O., Downing, J., \& Field, M. (2006). Globalization and the Small Firm: A Value Chain Approach to Economic Growth and Poverty Reduction. USAID, Microreport No. 42. 
M4P. (2008). Making Value Chains Work Better for the Poor: A Tool book for Practitioners of Value Chain Analysis (Version 3). Making Markets Work Better for the Poor (M4P) Project, UK Department for International Development (DFID), Phnom Penh: Agricultural Development International (Part 4).

National Statistical Office (NSO), \& ICF Macro. (2011). Malawi Demographic and Health Survey 2010. Zomba, Malawi and Calverton, Maryland, USA: NSO \& ICF Macro.

Prahalad, C. K., \& Hart L. S. (1999). Strategies for the Bottom of the Pyramid: Creating Sustainable Development. Draft.

Ravaillon, M. (2004). Competing Concepts of Inequality in the Globalization Debate. World Bank Policy Research Working Paper 3243, March 2004.

Riisgaard, L., Bolwig, S., du Toit, A., Matose, F., Hallberg, N., \& Ponte, S. (2008). Tools for Action Research with Small Producers in Global Value Chains. Unpublished Script, Copenhagen, Danish Institute for International Studies.

Seisay, M. B. D., van Zalinge, N. P., \& Turner, G. F. (1992). Population Dynamics and Stock Estimates of Chambo (Oreochromis spp.) in the South East Arm of Lake Malawi and Lake Malombe-Length Based Approach. Chambo Fisheries Research Project, GoM/FAO/UNDP, FI: DP/MLW/86/013, Field Document 19. Retrieved March 12, 2013, from http:/www.fao.org/docrep/006/AD204E/AD204E01.htm

Vermeulen, S., Woodhill, J., Proctor, F., \& Delnoye, R. (2008). Chain-Wide Learning for Inclusive Agrifood Market Development: A Guide to Multi-Stakeholder Process for Linking Small-Scale Producers to Modern Markets. International Institute for Environment and Development, London, UK and Wageningen University and Research Centre, Wageningen, the Netherlands.

\section{Notes}

Note 1. Conversion rate was 172 Malawi Kwacha to a US Dollar of 2011.

\section{Appendices}

Appendix 1. Matrix for upgrading possibilities

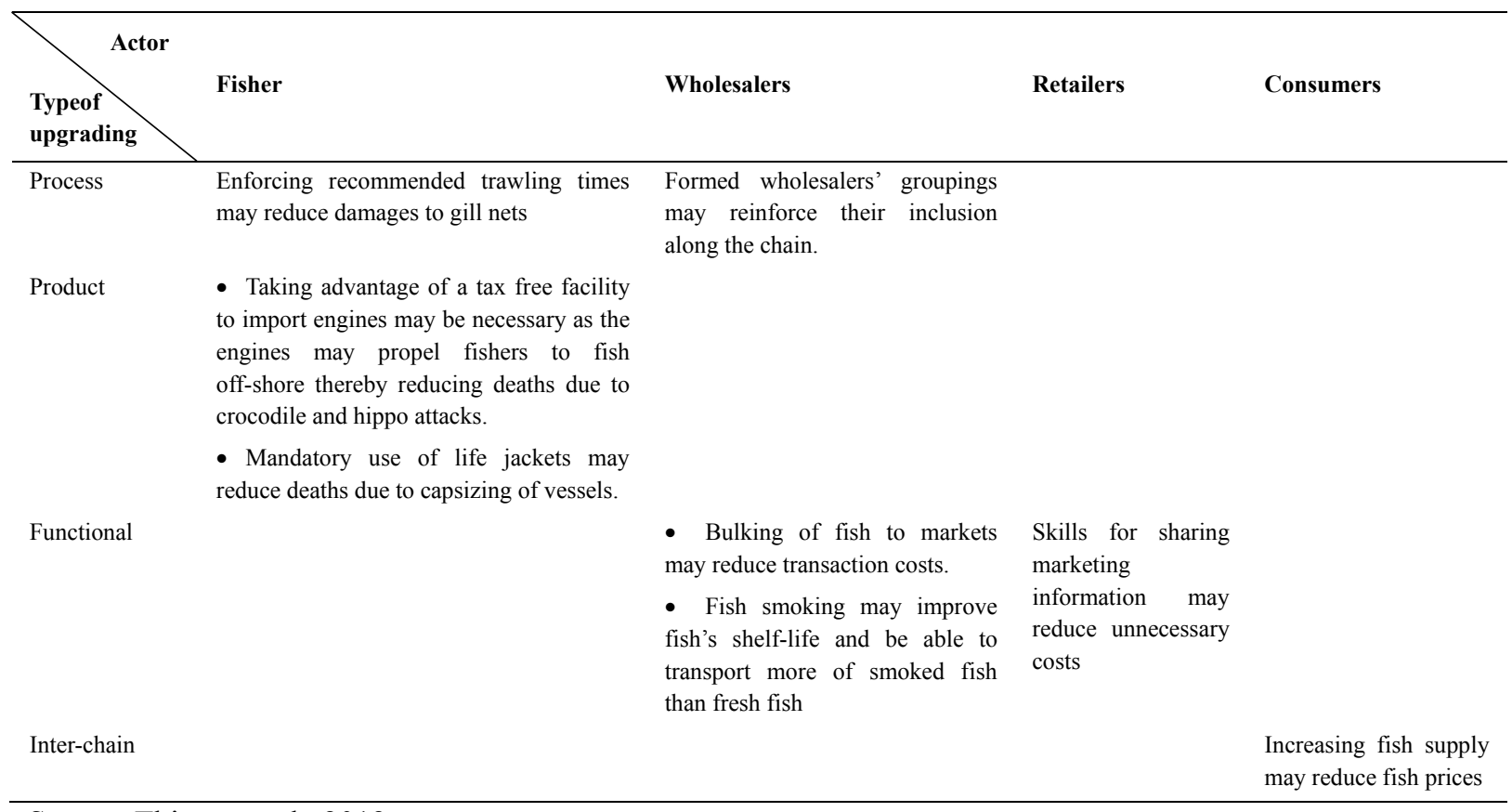

Source: This research, 2012. 


\section{Copyrights}

Copyright for this article is retained by the author(s), with first publication rights granted to the journal.

This is an open-access article distributed under the terms and conditions of the Creative Commons Attribution license (http://creativecommons.org/licenses/by/3.0/). 